\title{
METODE PENGEMBANGAN MOTORIK KASAR ANAK USIA DINI
}

\author{
Sumiyati \\ Institut Pesantren Mathali'ul Falah Pati (IPMAFA) Jawa Tengah \\ Email: atikpaudi@gmail.com
}

\section{Article received: 22 Februari 2018, Review process: 15 Maret 2018} Article published: 30 Maret 2018

\begin{abstract}
Early age is a golden age for growth and development of children. The child has a tremendous growth period at this age. All aspects of these developments need to get stimulation and support from parents, family and the environment, in order to run optimally in accordance with the task of child development, at every stage of his age. Aspects of child development include aspects of the development of moral, cognitive, social, emotional, self-reliance, language, motor skills and art. Aspects of child development that is easily visible is the aspect of physical motor development, especially rough motor development. The crude motor development aspect of the child is easily visible because it deals with physical activity. The growth and development of each child is not the same, it is influenced by genetic factors and environmental factors. This research was conducted at TK Bina Bhakti Sari Pati, with the method that was done was observation, in-depth interview and documentation. The results of the research in the form of instructions and recommendations for parents and teachers in order to provide stimulation to develop a rough motorcycle early childhood this is with; the first is creative play (crative learning), where children are fully involved in the play. Second, designing theme-based thematic activities and the third by utilizing the media as a tool to help children understand the activities and physical activities that will be done.
\end{abstract}

\section{Keywords: Motoric Rough, Early Childhood}

\begin{abstract}
Abstrak
Usia dini merupakan usia emas bagi pertumbuhan dan perkembangan anak. Anak mengalami periode perkembangan yang luar biasa di usia ini. Seluruh aspek perkembangan tersebut perlu mendapatkan stimulasi dan dukungan yang baik dari orangtua, keluarga dan lingkungan, supaya dapat berjalan dengan optimal sesuai dengan tugas perkembangan anak, di setiap tahapan usianya. Aspek perkembangan anak tersebut meliputi aspek perkembangan nilai agama moral, kognitif, sosial emosional kemandirian, berbahasa, fisik motorik dan seni. Aspek perkembangan anak yang mudah terlihat adalah aspek perkembangan fisik motorik, terutama perkembangan motorik kasar. Aspek perkembangan motorik kasar anak mudah terlihat karena berhubungan dengan aktifitas fisik. Pertumbuhan dan perkembangan pada setiap anak tidaklah sama, hal ini dipengaruhi oleh faktor genetik dan faktor lingkungan. Penelitian ini dilakukan di TK Bina Bhakti Sari Pati, dengan metode yang dilakukan yaitu observasi, wawancara mendalam dan dokumentasi. Hasil penelitian berupa petunjuk dan rekomendasi bagi orangtua maupun guru agar dapat memberikan stimulasi untuk mengembangkan motorik kasar anak usia dini ini yaitu dengan; pertama kegiatan main kreatif (creative learning), di mana anak terlibat secara penuh di dalam kegiatan main. Kedua, mendesain kegiatan main berbasis tema (tematik) dan yang ketiga dengan memanfaatkan media sebagai alat bantu untuk memudahkan anak memahami kegiatan dan aktivitas fisik yang akan dilakukannya.
\end{abstract}

Kata Kunci: Motorik Kasar, Anak usia dini 


\section{PENDAHULUAN}

Pertumbuhan dan perkembangan Anak Usia Dini (AUD) merupakan faktor penting yang tidak dapat diabaikan di usia keemasan anak. Usia emas (golden ages) adalah usia di mana seorang anak berada pada rentang usia lahir sampai dengan usia kurang lebih 6 tahun. Sehingga pada rentang usia inilah anak perlu mendapatkan stimulasi maksimal bagi seluruh aspek perkembangannya. Pendidikan Anak Usia Dini (PAUD) dewasa ini semakin banyak mendapat perhatian, baik dari pemerintah maupun masyarakat. Hal ini merupakan angin segar bagi dunia pendidikan anak usia dini, karena pendidikan di usia ini, akan membawa dampak yang sangat signifikan bagi tumbuh kembang anak selanjutnya. PAUD adalah adalah suatu upaya pembinaan yang ditujukan kepada anak sejak lahir sampai dengan usia enam tahun yang dilakukan melalui pemberian rangsangan pendidikan untuk membantu pertumbuhan dan perkembangan jasmani dan rohani agar anak memiliki kesiapan dalam memasuki pendidikan lebih lanjut (UU Sisdiknas, 2003: no.20).

Saat baru lahir, bayi hanya bisa mengandalkan gerakan refleks alami, gerakan refleks inilah cara bayi untuk dapat menyesuaikan diri dengan lingkungan barunya. Melalui gerakan refleks inilah satu-satunya cara yang dikuasai oleh bayi, sampai bayi dapat melihat secara sempurna dan otot-ototnya tumbuh lebih kuat (Denidya, 2013: 13). Allah mengkaruniakan gerakan refleks bayi ini sebagai kemampuan bawaan yang dimiliki sang bayi untuk bertahan hidup di lingkungan baru, saat usia baru lahir, seorang bayi masih sangat bergantung pada kasih sayang orang lain, bayi membutuhkan pertolongan, kasih sayang dan perawatan dari orang lain, yaitu dari orangtua maupun orang-orang di sekitarnya. Gerak refleks bayi dapat terlihat pada kemampuan bayi yang dengan refleks menggenggam jari ibu yang ditempel ke telapak tangannya. Bayi juga akan berusaha menoleh ke arah sentuhan lembut di pipinya. Sehingga rangsangan-rangsangan ini dapat terus diberikan supaya bayi dapat tumbuh dengan maksimal sesuai dengan tahap perkembangan.

Pemberian rangsangan pendidikan perlu dilakukan pada seluruh aspek perkembangan anak. pemberian rangsangan ini akan dapat optimal apabila dilakukan di usia dini, di mana usia dini merupakan usia anak untuk dapat mudah menyerap berbagai stimulasi yang diberikan. Aspek-aspek perkembangan anak yang perlu mendapatkan perhatian tersebut antara lain adalah aspek perkembangan berbahasa, aspek perkembangan nilai agama moral, aspek perkembangan fisik motorik (motorik kasar maupun motorik halus), aspek perkembangan sosial emosional kemandirian, dan aspek perkembangan kognitif, serta aspek 
perkembangan seni, keenam aspek perkembangan anak ini, akan dapat berkembang dengan optimal apabila mendapatkan stimulasi yang tepat dari lingkungan, baik lingkungan keluarga, lingkungan sekolah, maupun lingkungan masyarakat. Agar dapat memberikan stimulasi yang baik, maka orangtua harus aktif mengetahui setiap perkembangan anak-anaknya, karena sejatinya, tanggung jawab pendidikan usia dini merupakan tanggungjawab dari orangtua, orangtua berperan sebagai guru pertama dan utama bagi anak, pendidikan anak juga merupakan tanggungjawab keluarga, karena keluargalah yang berfungsi sebagai madrasah pertama bagi anak-anak, sedangkan sekolah dan lingkungan berfungsi sebagai faktor pendukung.

Aspek perkembangan yang mudah dikenali dan terlihat pada anak adalah aspek perkembangan motoriknya, terutama perkembangan motorik kasarnya. Pertumbuhan dan perkembangan motorik kasar anak dapat dilihat dari tahap pencapaian perkembangan anak itu sendiri. Seperti anak usia lima belas bulan seharusnya sudah dapat berjalan dengan baik. Sebelum anak dapat berjalan dengan baik, awalnya anak akan berlatih berdiri sambil berpegangan pada benda-benda di sekitar anak, lalu di hari lain mungkin akan sedikit demi sedikit melangkah sambil tetap berpegangan, selanjutnya sambil terhuyung-huyung ia mungkin akan menghampiri tangan ibunya untuk meminta bantuan (Denidya, 2013: 134). Apabila di usia tersebut anak masih belum dapat berjalan, sebaiknya orangtua perlu waspada, karena mungkin terjadi keterlambatan dalam perkembangan motoriknya. Jika hal ini terjadi orangtua sebaiknya segera mencari tahu faktor penyebab terjadinya keterlambatan tersebut, sehingga dapat segera mencari solusi atau pemecahan mengapa sampai usia tersebut anak belum dapat berjalan, sebagaimana tugas perkembangannya.

Sering kita jumpai di masyarakat kita bahwa terkadang faktor keterlambatan dari kemampuan anak untuk dapat berjalan dipengaruhi oleh pola asuh yang kurang tepat. Pola asuh yang kurang tepat ini dapat terlihat dari kurangnya orangtua memberikan kesempatan kepada anak untuk melatih kakinya berjalan. Misal seperti kebiasaan orangtua atau pengasuh yangselalu menggendong anak dengan alasan takut kotor apabila bermain di lantai, atau takut anak akan terjatuh, takut rumah berantakan dan lain sebagainya, tentu saja hal ini menghambat kemampuan berjalan anak, anak juga akan terbiasa dengan pola asuh yang kurang tepat tersebut, dan berimbas pada kurang percaya dirinya anak untuk berlatih berjalan, anak akan merasa takut dan tidak terbiasa untuk menjejakkan kakinya di lantai. Orangtua sebaiknya memperbolehkan anak untuk bermain di lantai, di tanah, dan di tempat-tempat yang 
dapat merangsang perkembangan anak. Tempat bermain anak yang perlu diperhatikan adalah keamanan dan kenyamanan, sehingga apabila dalam kegiatan main tersebut mengakibatkan kotor, maka orangtua dapat segera membersihkan diri dengan mandi, atau mencuci tangan dan kaki anak, dengan demikian tidak ada alasan anak tidak boleh bermain dengan tanah, tidak boleh bermain di lantai karena kotor.

Selain kebiasaan menggendong dan takut kotor, sebagian masyarakat juga meyakini adanya kepercayaan bahwa anak belum dapat berjalan atau anak terlambat berjalan karena anak menguasai kemampuan berbahasanya lebih dahulu, yaitu kemampuan bahasa lisan (kemampuan berbicara anak). Anggapan ini lebih mengarah kepada mitos yang diyakini oleh sebagian masyarakat. Dengan demikian masyarakat menganggap bahwa kelak suatu saat anaknya akan dapat berjalan dengan sendirinya tanpa perlu dikhawatirkan, meskipun mengalami keterlambatan di dalam perkembangannya, sehingga keterlambatan pada aspek perkembangan motorik anak (berjalan) merupakan hal yang wajar, mengingat ada kemajuan perkembangan pada aspek perkembangan anak yang lain, yaitu aspek perkembangan berbahasa.Pada usia dini perkembangan anak terjadi sangat cepat. Termasuk perkembangan fisik motorik anak terjadi dengan begitu pesat. Perkembangan motorik tidak saja mencakup berjalan, berlari, melompat, dapat naik sepeda roda tiga, mendorong, menarik, memutar dan berbagai aktivitas koordinasi mata tangan, namun juga melibatkan hal-hal seperti menggambar, mengecat, mencoret dan kegiatan lain yang berhubungan dengan motorik anak. Keterampilan motorik berkembang pesat pada usia ini (Reni Akbar, 2001:7). Aspek perkembangan motorik anak pada dasarnya terbagi dalam dua kategori, yaitu perkembangan motorik kasar dan perkembangan motorik halus. Keduanya memerlukan perhatian dan stimulasi yang tepat di usia kanak-kanak. Dari keduanya, perkembangan motorik kasar anak akan mudah terlihat karena motorik kasar berhubungan dengan gerakan-gerakan fisik yang membutuhkan koordinasi otot besar.

TK Bina Bhakti Sari tepatnya terletak di desa Purwosari Kecamatan Tlogowungu Kabupaten Pati. Memiliki 30 anak didik dengan 2 orang guru dan 1 kepala sekolah. Berdasarkan obeservasi awal yang dilakukan oleh penulis, anak-anak di lembaga tersebut cenderung menerima stimulasi atau kegiatan pembelajaran yang mengarah kepada perkembangan kognitif saja. Di mana anak-anak lebih banyak diarahkan untuk membaca atau menulis dan berhitung, kesempatan mengembangkan aspek fisik motorik hanya dilakukan sekedarnya saja seperti saat senam, dan saat kegiatan olahraga. Demikian pula hasil 
wawancara dengan kepala sekolah dan guru, bahwa di TK Bina Bhakti Sari pengembangan fisik motorik anak bukan menjadi prioritas utama, karena banyak orangtua murid yang menghendaki dan berharap setelah lulus TK anak-anak dapat membaca dan menulis. Sedangkan pengembangan aspek fisik motorik anak mereka berpendapat dapat berkembang dengan sendirinya. Hal inilah yang mendorong penulis untuk melakukan penelitan tentang metode pengembangan fisik motorik anak di lembaga tersebut.

\section{METODOLOGI}

Metode penelitan yang penulis gunakan adalah dengan metode kualitatif. Pengambilan dan pengumpulan data dilakukan secara kualitatif dengan wawancara mendalam (in depth interview) dan observasi. Wawancara mendalam ini penulis lakukan kepada Kepala sekolah, guru, anak-anak, dan juga kepada wali murid di TK Bina Bhakti Sari. Selanjutnya penulis melakukan observasi. Melaui observasi ini penulis dapat mengetahui permasalahan dan keadaan di lapangan yang sesungguhnya. Terakhir penulis menggunakan metode dokumentasi.

\section{HASIL DAN PEMBAHASAN}

\section{Pertumbuhan dan perkembangan anak usia dini}

Perkembangan anak usia dini sifatnya holistic, yaitu dapat berkembang optimal apabila sehat badannya, cukup gizinya, dan dididik secara baik dan benar. Anak berkembang dari berbagai aspek yaitu berkembang fisiknya, baik motorik kasar maupun halus, berkembang aspek kognitif, aspek sosial, dan emosional (Mursyid, 2015: 121). Dengan demikian, anak dapat tumbuh dan berkembang dengan baik apabila seluruh aspek yang mendukung tumbuh kembangnya dapat terpenuhi dengan baik, baik berupa stimulasi untuk petumbuhan fisiknya seperti terpenuhi kebutuhan gizi dan nutrisi sehari-hari, maupun untuk kebutuhan mentalnya berupa perhatian dan kasih sayang dari orangtua dan anggota keluarga serta adanya penerimaan dari lingkungannya.

Pertumbuhan sering diartikan sebagai segala sesuatu perubahan yang dapat terlihat secara langsung, dan sering diidentikkan dengan perubahan fisik anak. Pertumbuhan berkaitan dengan masalah perubahan dalam bentuk besar, jumlah, ukuran organ individu yang dapat diukur melaluiukuran berat, ukuran panjang, besar lingkaran kepala. Semua perubahan ini memerlukan proses pemantauan dan stimulasi yang tepat. Pertumbuhan dapat dicontohkan seperti pertumbuhan fisik anak, dari kecil ke besar, dari pendek ke tinggi, dari awalnya anak belum ada gigi, menjadi tumbuh gigi dan sebagainya. Sedangkan perkembangan adalah 
bertambahnya kemampuan (skill) dalam struktur dan fungsi tubuh yang lebih kompleks dengan pola yang teratur dan dapat diramalkan, sebagai hasil dari proses pematangan individu. Proses terjadinya perkembangan ini, biasanya berkaitan erat dengan masalah psikologis seperti kemampuan gerak kasar dan halus, intelektual, sosial dan emosional, proses penanaman nilai-nilai keagamaan, serta perkembangan afektif lainnya, misal kemampuan anak untuk dapat berbagi dengan temannya, mau meminta maaf apabila melakukan kesalahan, mampu mengucap terimakasih apabila menerima bantuan, dan seterusnya.

Tumbuh kembang anak merupakan proses pertumbuhan fisik, dan proses perkembangan kemampuan mental intelegensi serta perilaku anak, sehingga pertumbuhan dan perkembangan anak merupakan sesuatu yang sangat kompleks dan saling terkait. Terdapat dua faktor utama yang dapat mempengaruhi proses tumbuh kembang anak, yaitu faktor genetik (faktor keturunan) dan faktor lingkungan. Faktor lingkungan yang mempengaruhi proses tumbuh kembang anak sangatlah beragam, seperti faktor makanan yang dikonsumsi anak, faktor kecukupan gizi yang diperoleh anak, faktor sosial ekonomi keluarga, serta faktor kesehatan.

Faktor genetik merupakan faktor bawaan yang menunjukkan potensi. Faktor ini tidak dapat dimanipulasi, karena telah dibawa oleh anak sejak lahir. Sedangkan faktor lingkungan merupakan faktor eksternal yang keberadaannya menentukan apakah potensi anak dapat tercapai atau tidak, faktor lingkungan ini dapat dimanipulasi dan diupayakan keberadaannya. Faktor lingkungan dapat dimanipulasi dan diupayakan sebaik mungkin melalui pola pengasuhan yang tepat, dapat pula diupayakan dengan memberikan kecukupan kebutuhan gizi secara fisik, seperti kecukupan nutrisi yang dibutuhkan. Kecukupan gizi anak harus memperhatikan tingkat kebutuhan protein, banyaknya energi yang dibutuhkan anak untuk dapat beraktifitas, mengandung cukup lemak, vitamin dan mineral yang sesuai, serta kesiapan pelayanan kesehatan, juga stimulasi fisik yang baik. Status gizi anak harus baik, apabila kita menginginkan anak dapat tumbuh dengan sehat. Apabila status gizi baik, maka anak akan dapat tumbuh dengan optimal. Demikian sebaliknya, apabila anak menderita gizi buruk, maka tumbuh kembang anak juga akan mengalami gangguan.

Orangtua harus dapat menyesuaikan perkembangan fisik bayi dengan pola makannya, selama masih dalam pemantauan orangtua dan dokter anak, bayi akan mencapai proses tumbuh kembang secara optimal. Beberapa hal yang penting untuk diingat seberapa banyak dan seberapa sering bayi makan, semuanya tergantung pada usia, tingkat pertumbuhan, berat 
badan, dan metabolisme. Perkembangan bayi tersebut tidak sama antara satu bayi dengan bayi yang lainnya (Kirania, 2009: 113). Organ penting yang mempengaruhi kecerdasan seorang anak adalah otak. Oleh karena itu, asupan gizi yang tepat dan sedini mungkin pada otak anak tentunya akan berpengaruh terhadap kecerdasan seseorang. Dengan demikian, tidaklah mengherankan apabila kita mendengar kata cerdas, maka kita akan selalu mencari kaitannya dengan kata otak (Novaria, 2008: 63). Kecukupan gizi secara mental juga menjadi faktor penting seperti terpenuhinya kasih sayang, kebutuhan akan rasa aman, kebutuhan untuk dilindungi dan stimulasi mental yang baik selama tumbuh kembang anak serta perlakuan secara emosional yang baik merupakan kebutuhan mental anak yang wajib dipenuhi selain kebutuhan-kebutuhan fisik anak. Kebutuhan anak akan kasih sayang merupakan faktor yang penting yang harus diterima anak. Kasih sayang yang diterima anak akan membuat anak merasa diterima dan mendapat dukungan untuk dapat tumbuh dan berkembang sesuai dengan tugas-tugas perkembangan anak yang dimilikinya.

Orangtua memegang peranan penting dalam proses tumbuh kembang anak, hal-hal yang perlu diperhatikan oleh orangtua di saat mendampingi anak pada masa-masa pertumbuhan antara lain (Kirania, 2009: 14), anak belajar melalui inderanya, anak akan melihat dan mempelajari segala hal yang dilihatnya, meniru dan merekam dengan baik apa yang didengarnya. Anak memberikan tanggapan pada lingkungan yang beragam. Anak belajar dari meniru. Anak belajar dari berbagai macam permainan. Anak belajar dari pengulangan. Anak berkembang melalui pengalaman. Anak belajar lebih cerdas melalui pemecahan masalah. Anak belajar melalui bahasa. Anak melangkah maju dalam kecepatannya sendiri. Anak melakukan aktifitasnya berkat kepercayaan dirinya. Murid-murid di TK Bina Bhakti Sari belum mendapatkan kesempatan main yang cukup, hal ini disebabkan masih kurangnya perhatian guru terhadap kegiatan pengembangan fisik motorik anak di sekolah. Di samping itu sebagaian besar murid masih ditunggui oleh orangtuanya, sehingga dalam melakukan segala aktifitas, anak-anak masih banyak dibantu oleh orangtuanya.

\section{Motorik Kasar Anak}

Perkembangan fisik motorik merupakan salah satu perkembangan mendasar yang dibutuhkan anak untuk proses tumbuh kembang selanjutnya. Perkembangan motorik adalah kegiatan yang berhubungan dengan otot, otak, dan syaraf (Dwi, 2008:54). Anak usia 3-4 tahun sedang berada dalam masa emas perkembangan motorik, terutama motorik kasar. Anak menyenangi kegiatan fisik, mulai mengembangkan keterampilan baru dan memperbaiki 
keterampilan yang dimiliki sebelumnya. (Winda Gunarti, 2008: 4.14). Motorik dapat diartikan sebagai perkembangan pengendalian gerakan jasmani melalui kegiatan-kegiatan pusat syaraf, urat syaraf, dan juga otak yang saling terkoordinasi. Pengendalian tersebut berasal dari refleksi dan kegiatan masa yang ada, pada waktu lahir sebelum perkembangan-perkembangan tersebut terjadi, maka anak akan tetap tidak berdaya sehingga butuh pertolongan orang lain. Sedangkan kemampuan motorik kasar adalah kemampuan yang membutuhkan koordinasi sebagian besar bagian-bagian tubuh anak yang biasanya memerlukan tenaga, hal ini disebabkan karena gerakan-gerakan dilakukan oleh koordinasi otot-otot yang lebih besar. (Elizabeth Hurlock, 2005: 151).

Perkembangan motorik kasar merupakan wilayah terpenting pada pertumbuhan dan perkembangan anak di usia dini. Kemampuan motorik kasar anak diawali dengan kemampuan anak untuk berjalan, kemudian berlari dan melompat, dan selanjutnya kemampuan anak untuk melempar. Modal dasar untuk perkembangan motorik kasar anak ini ada tiga, yaitu yang berkaitan dengan sensoris utama, yaitu keseimbangan (vestibuler), berhubungan dengan persendian (propriosepsi), yang berhubungan dengan perabaan (taktil) (Maimunah Hasan, 2015: 95). Senada dengan pendapat di atas, motorik kasar juga dapat diartikan sebagai gerakan tubuh yang menggunakan otot-otot besar atau sebagian besar atau seluruh anggota tubuh yang dipengaruhi oleh kematangan anak itu sendiri, sehingga kematangan merupakan faktor penting di dalam optimalisasi kendali dari sensoris utama (Siti Aisyah, 2008: 4.42).

Keseimbangan, kesiapan persendian dan kekuatan otot, serta perabaan merupakan sasaran awal bagi perkembangan motorik kasar anak. Tahap perkembangan yang dilakukan anak dapat diramalkan, sehingga orangtua dan lingkungan dapat memberikan stimulasi dan dukungan secara maksimal. Yang dimaksudkan bahwa perkembangan anak dapat diramalkan adalah bahwa tahah-tahap perkembangan anak dapat diketahui sebelumnya, misal setelah anak dapat menyangga kepalanya sendiri, perkembangan anak selanjutnya adalah tengkurap, setelah anak dapat tengkurap dengan baik, maka anak akan belajar untuk duduk, setelah dapat duduk, maka anak akan belajar untuk merangkak, kemudian anak akan belajar berdiri berpegangan, berdiri tanpa pegangan dan selanjutnya anak akan belajar untuk berjalan, sampai akhirnya anak belajar berlari, dan seterusnya.

Banyak hal yang dapat dilakukan untuk membantu memaksimalkan perkembangan motorik kasar anak, sejumlah kegiatan atau permainan beserta alat permainan edukatif dapat digunakan untuk mengembangkan motorik kasar anak. Keterampilan menggunakan gerakan- 
gerakan bagian tubuh untuk melatih ketangkasan merupakan bagian dari pengembangan motorik kasar. Banyak alat-alat main yang sederhana dan mudah di temukan serta dapat digunakan untuk memaksimalkan pengembangan motorik kasar ini, seperti titian untuk meniti sambil mata melihat lurus ke depan, bola sebagai media permainan lempar tangkap bola, anak-anak dapat menggunakan bola tersebut untuk dilempar dan ditangkap, dan lain sebagainya (Anggani Sudono, 2000: 54). Selain menggunakan media, pengembangan motorik kasar juga dapat dilakukan dengan kegiatan-kegiatan langsung tanpa media atau tanpa bantuan alat permaian edukatif. Kegiatan pengembangan motorik kasar tanpa media dapat dirancang semenarik mungkin dengan berbagai variasi, seperti dengan cara bertepuk tangan dengan berbagai variasi, bermain ular naga dengan mengandalkan kemampuan gerakan kaki dan tangan anak, berlari, berjalan, berjinjit, meniru gerakan-gerakan binatang, menari, dan masih banyak kegiatan-kegiatan menarik lainnya yang dapat dilakukan.

Setidaknya ada tiga tahapan penting dalam perkembangan motorik kasar anak. Tiga tahapan tersebut adalah pertama tahap kognitif. Tahap kognitif yaitu tahapan di mana anak berusaha mengingat gerakan-gerakan yang pernah dilakukan sebelumnya. Kedua, yaitu tahapan asosiatif. Tahapan asosiatif yaitu tahapan di mana anak melakukan kegiatan "trial and error" anak akan mencoba berbagai gerakan, mengulang-ulang gerakan tersebut, dan mengoreksi gerakan-gerakannya sendiri. Ketiga adalah adalah autonomous, yaitu anak sudah secara otomatis dapat menampilkan atau melakukan gerakan-gerakan dengan sedikit kesalahan yang dibuatnya.

Para pakar mengelompokkan gerakan motorik kasar ke dalam tiga hal pokok, yaitu tahap lokomotor, yaitu gerakan yang mengakibatkan perpindahan tempat, seperti berjalan, berlari, melompat dan meluncur. Tahap non lokomotor, yaitu gerakan yang tidak memerlukan perpindahan tempat, seperti mengangkat, mendorong, menarik, dan berayun. Selanjutnya adalah tahap memproyeksi, yaitu tahap memproyeksikan sesuatu benda seperti gerakan melempar dan menangkap, hal ini dapat dilihat dari kemampuan anak dalam bermain lempar tangkap bola. Aspek perkembangan motorik kasar anak adalah gerak dasar yang dapat dikembangkan sejak awal, dan berhubungan dengan kesehatan dan kebugaran fisik anak (Bambang Sujiono, 2014: 1.3.)

Aspek-aspek perkembangan motorik kasar anak yang perlu mendapat perhatian antara lain pertama, adalah aspek kekuatan. Kekuatan, yaitu kemampuan seseorang anak untuk dapat menggunakan kekuatan atau kelompok otot agar berfungsi untuk menahan, dan mengangkat 
beban. Kedua daya tahan, yaitu daya tahan adalah kemampuan seorang anak untuk bekerja (bermain) atau berkegiatan dalam waktu yang cukup lama tanpa mengalami kelelahan yang berarti, seperti berjalan cepat, dan berlari. Ketiga yaitu kecepatan, kecepatan yaitu kemampuan seseorang untuk bergerak atau berpindah dari satu tempat ke tempat yang lain dalam waktu singkat, seperti berlari menuju tempat tertentu dengan cepat. Keempat, adalah keseimbangan. Keseimbangan merupakan kemampuan seorang anak untuk mempertahankan posisi tubuh dan equilibrium secara bersama-sama selama bergerak dan dalam keadaan tepat. Kelima adalah koordinasi, koordinasi adalah kemampuan seseorang anak untuk menggabungkan bermacam-macam gerakan yang berbeda ke dalam pola gerakan yang tunggal secara efektif, seperti memantulkan bola ke lantai, koordinasi ini perlu mendapatkan stimulasi berulang sehingga anak dapat mahir melakukannya. Selanjutnya adalah kelincahan. Kelincahan, merupakan emampuan seseorang untuk menganti posisi dan arah dalam waktu yang singkat, seperti bermain kejar-kejaran, berlari berkelak-kelok. Dan yang terakhir adalah ketepatan. Ketepatan, adalah kemampuan seseorang untuk mengendalikan gerak-gerak bebas terhapap suatu objek atau sasaran. Seperti kemampuan anak melempar bola agar masuk ke dalam keranjang (basket ) pada jarak lempar tertentu yang telah ditentukan. Semua aspek perkembangan motorik kasar di atas dapat berjalan dan berkembang dengan optimal dengan stimulus-stimulus yang tepat, karena pada dasarnya dalam proses perkembangan anak, morik kasar anak akan berkembang terlebih dahulu dibandingkan motorik halusnya.

Dengan demikian penguasaan kemampuan motorik kasar pada anak merupakan hal penting yang perlu diperhatikan. Penting bagi para orangtua di rumah untuk memberikan lingkungan main yang dapat mengembangkan kemampuan ini. Para orangtua harus dapat memulai kembali memberikan ruang bermain anak yang melibatkan aktifitas fisiknya, sehingga anak tidak hanya asyik bermain gadget, menonton televisi, play station, di mana permainan-permainan tersebut tidak melibatkan banyak gerakan tubuh. Sayangnya orangtua sekarang lebih senang anaknya bermain di dalam rumah, dengan alasan apabila di luar rumah akan kotor, panas, dan sebagainya. Padahal justru bermain di luar rumah inilah yang dapat memaksimalkan perkembangan motorik kasar anak.

\section{Perkembangan Motorik Kasar Anak}

Anak-anak akan mulai melakukan gerakan-gerakan sebagai bentuk kemampuan motoriknya dengan sesuatu yang paling mudah dan sederhana. Kemampuan motorik kasar anak dapat dimaksimalkan tidak hanya ketika anak sudah bergabung di lembaga sekolah, atau 
bagi anak usia dini, stimulasi perkembangan motorik kasar anak tidak hanya menunggu ketiaka anak sudah berada di lembaga Pendidikan Anak Usia Dini (PAUD), akan tetapi dapat juga dilaksanakan di rumah, yaitu oleh orangtua maupun anggota keluarga yang lain, dengan mengetahui kemampuan-kemampuan motorik yang dimiliki oleh anak. Sebagaimana tingkatan kemampuan motorik anak yang dapat dijelaskan di bawah ini (Sri Suciati, 2015: 165):

a. Imitation (peniruan). Peniruan yaitu suatu keterampilan untuk menirukan sesuatu gerakan yang telah dilihat, didengar atau dialaminya. Seorang anak dengan kemampuan menirunya, akan berusaha melakukan gerakan-gerakan yang dipelajarinya dari melihat, mendengar dan contoh dari lingkungan sekelilingnya.

b. Manipulation(penggunaan konsep). Perkembangan kemampuan mengikuti pengarahan, penampilan gerakan-gerakan pilihan dan menetapkan suatu penampilan melalui latihan. Anak akan berusaha mengulang dan melakukan gerakan baru yang depelajarinya dari sekeliling, kemudian lambat laun dapat menguasai gerakan itu.

c. Precition (ketelitian). Suatu keterampilan yang berhubungan dengan kegiatan melakukan gerakan secara teliti dan benar. Anak akan mahir melakukan suatu gerakan tertentu, setelah melakukan pengulangan-pengulangan yang dilakukannya.

d. Articulation (perangkaian). Suatu keterampilan untuk merangkaikan bermacam-macam gerakan secara berkesinambungan.

e. Naturalization (kewajaran/ pengalamiahan) Suatu keterampilan untuk melakukan gerakan secara wajar menurut tingkah laku yang ditampilkan, gerakan ini paling sedikit mengeluarkan energi baik fisik maupun pesikis.

Perkembangan motorik kasar anak juga dipengaruhi oleh faktor nutrisi yang diterima oleh anak. Masa kanak-kanak merupakan masa yang mengharuskan kecukupan gizi dan nutrisi yang seimbang, sehingga anak dapat tumbuh dan menjalankan tugas perkembangannya dengan baik. Ibu memegang peran penting dalam usaha memenuhi kecukupan gizi anak. asupan yang diterima oleh anak haruslah seimbang dan sesuai dengan angka kebutuhan gizi yang dibutuhkan oleh anak-anak, tidak kurang dan tidak juga lebih. 
Tingkat pencapaian perkembangan fisik motorik kasar anak usia dini seseuai dengan lampiran Peraturan Menteri Pendidikan dan Kebudayaan Nomor 137 tahun 2014 dapat dilihat pada tabel berikut (Permendikbud, 2014: 137).

\begin{tabular}{|c|c|c|c|}
\hline \multicolumn{4}{|c|}{ Kelompok Usia } \\
\hline 3 bulan & 3-6 bulan & 6-9 bulan & 12 bulan \\
\hline 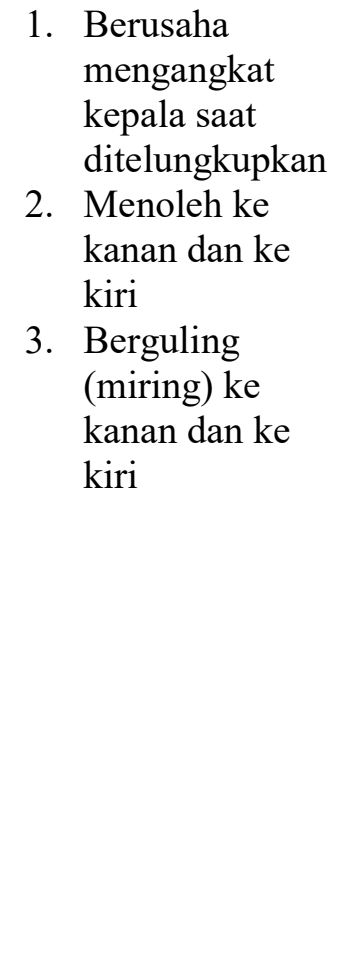 & $\begin{array}{ll}\text { 1. Tengkurap dengan } \\
\text { dada diangkat dan } \\
\text { kedua tangan } \\
\text { menopang } \\
\text { 2. Duduk dengan } \\
\text { bantuan } \\
\text { 3. Mengangkat kedua } \\
\text { kaki saat terlentang } \\
\text { 4. Kepala tegak ketika } \\
\text { duduk dengan } \\
\text { bantuan }\end{array}$ & 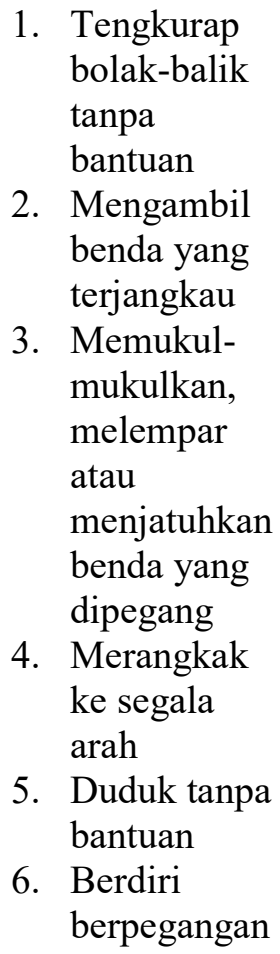 & $\begin{array}{l}\text { 1. Berjalan } \\
\text { dengan } \\
\text { berpegangar } \\
\text { 2. Bertepuk } \\
\text { tangan }\end{array}$ \\
\hline \multicolumn{2}{|c|}{12 bulan-18 bulan } & \multicolumn{2}{|c|}{18 bulan-24 bulan } \\
\hline \multicolumn{2}{|c|}{ 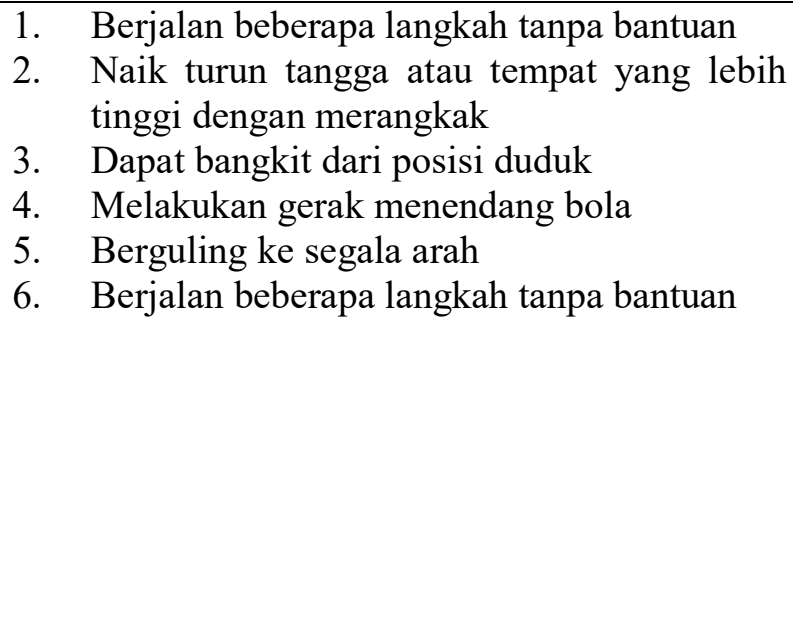 } & \multicolumn{2}{|c|}{$\begin{array}{l}\text { 1. Berjalan sendiri tanpa jatuh } \\
\text { 2. Melompat di tempat } \\
\text { 3. Naik turun tangga atau tempat } \\
\text { yang lebih tinggi dengan bantuan } \\
\text { 4. Berjalan mundur beberapa } \\
\text { langkah } \\
\text { 5. Menarik dan mendorong benda } \\
\text { yang ringan (kursi kecil) } \\
\text { 6. Melempar bola ke depan tanpa } \\
\text { kehilangan keseimbangan } \\
\text { 7. Menendang bola ke arah depan } \\
\text { 8. Berdiri dengan satu kaki selama } \\
\text { 9. Berjongkok }\end{array}$} \\
\hline
\end{tabular}




\begin{tabular}{|c|c|}
\hline 2-3 tahun & 3-4 tahun \\
\hline $\begin{array}{l}\text { 1. Berjalan sambil berjinjit } \\
\text { 2. Melompat ke depan dan ke belakang dengan } \\
\text { dua kaki } \\
\text { 3. Melempar dan menangkap bola } \\
\text { 4. Menari mengikuti irama } \\
\text { 5. Naik-turun tangga atau tempat yang lebih } \\
\text { tinggi/rendah dengan berpegangan }\end{array}$ & $\begin{array}{l}\text { 1. Berlari sambil membawa sesuatu } \\
\text { yang ringan (bola) } \\
\text { 2. Naik-turun tangga atau tempat } \\
\text { yang lebih tinggi dengan kaki } \\
\text { bergantian } \\
\text { 3. Meniti di atas papan yang cukup } \\
\text { lebar } \\
\text { 4. Melompat turun dari ketinggian } \\
\text { kurang lebih } 20 \mathrm{~cm} \text { (di bawah } \\
\text { tinggi lutut anak) } \\
\text { 5. Meniru gerakan senam sederhana } \\
\text { seperti menirukan gerakan } \\
\text { pohon, kelinci melompat) } \\
\text { 6. Berdiri dengan satu kaki }\end{array}$ \\
\hline 4-5 tahun & 5-6 tahun \\
\hline $\begin{array}{l}\text { 1. Menirukan gerakan binatang, pohon tertiup } \\
\text { angin, pesawat terbang, dsb } \\
\text { 2. Melakukan gerakan menggantung } \\
\text { (bergelayut) } \\
\text { 3. Melakukan gerakan melompat, meloncat, dan } \\
\text { berlari secara terkoordinasi } \\
\text { 4. Melempar sesuatu secara terarah } \\
\text { 5. Menangkap sesuatu secara tepat } \\
\text { 6. Melakukan gerakan antisipasi } \\
\text { 7. } \\
\text { 8. } \\
\text { Menendang sesuatu secara terarah } \\
\text {. }\end{array}$ & $\begin{array}{l}\text { 1. Melakukan gerakan tubuh secara } \\
\text { terkoordinasi untuk melatih } \\
\text { kelenturan, keseimbangan, dan } \\
\text { kelincahan } \\
\text { 2. Melakukan koordinasi gerakan } \\
\text { mata-kaki-tangan-kepala dalam } \\
\text { menirukan tarian atau senam } \\
\text { 3. Melakukan permainan fisik } \\
\text { dengan aturan } \\
\text { 4. Terampil menggunakan tangan } \\
\text { kanan dan kiri } \\
\text { 5. Melakukan kegiatan kebersihan } \\
\text { diri }\end{array}$ \\
\hline
\end{tabular}

\section{Stimulasi Motorik Kasar Anak}

Sejak usia lahir stimulasi atau rangsangan untuk memaksimalkan perkembangan motorik kasar anak usia dini sudah dapat dilakukan. Dimulai dari usia lahir hingga usia 3 bulan anak sudah berada pada tingkat pencapaian perkembangan berupa mengangkat kepala dan menoleh ke kanan dan ke kiri serta memiringkan badannya, hal yang perlu dilakukan orangtua untuk menstimulasi perkembangan anak tersebut antara lain dengan memberikan stimulasi suara, yaitu indra pendengarannya. Orangtua dapat memulai stimulasi ini dengan memanggil nama si bayi. Ketika dipanggil, bayi akan memberikan respon dengan berusaha mencari sumber suara. Bayi akan menoleh ke kanan maupun ke kiri mengikuti sumber suara, 
stimulasi memanggil nama bayi adalah bagian dari memaksimalkan perkembangan motorik kasar anak di usia bayi.

Memasuki usia tiga sampai dengan enam bulan, tugas perkembangan anak meliputi tengkurap dengan dua tangan menopang badan, akan tetapi terkadang bayi belum dapat tengkurap dengan sempurna. Terkadang bayi akan tengkurap kemudian belum mampu membalikkan badannya kembali hingga akhirnya akan menangis. Orangtua dapat membantu anak untuk membalikkan badan atau mengarahkan anak ke posisi tengkurap, dan sebaliknya, bantuan dapat diberikan sesuai kebutuhan. Pada usia ini anak juga akan berlatih untuk duduk, pada usia ini tentu saja duduk dengan bantuan, sehingga kekuatan duduk masih berada pada tangan ibu atau orangtua yang menopang badan anak, masih pada usia ini, bayi akan berusaha mengangkat kepalanya sendiri. Yang perlu diperhatikan orangtua adalah tetap menopang kepala anak dengan memastikan leher tetap pada posisi aman, sehingga anak dapat merasa nyaman dan tidak terjadi cedera pada otot leher.

Perkembangan anak selanjutnya sampai pada kemampuan anak untuk dapat tengkurap sendiri. Anak sudah dapat tengkurap bolak balik dengan tanpa bantuan. Hal yang perlu diperhatikan oleh orangtua adalah memfasilitasi anak dengan tempat yang nyaman dan memudahkan anak untuk melakukan kegiatan tengkurap bolak balik ini. Perkembangan ini terjadi di usia enam sampai sembilan bulan, anak juga sudah mampu untuk mengambil benda yang ada di sekitarnya, kemudian melempar benda tersebut dan menjatuhkannya, atau sekedar memukul-mukul benda tersebut. Hal yang perlu diperhatikan oleh orangtua pada tahap perkembangan motorik kasar usia ini adalah pentingnya orangtua menyediakan benda-benda atau alat permainan yang tidak membahayakan keselamatan maupun kesehatan anak, alat permainan harus dipastikan aman untuk anak usia ini. Demikian pula penataan ruangan rumah, benda-benda di ruangan/di rumah juga harus diperhatikan, karena di usia ini anak sudah mulai belajar merangkak ke segala arah. Anak juga sudah mampu duduk tanpa bantuan, belajar berdiri sendiri tanpa berpegangan, hingga mampu berjalan dengan bantuan dan anak telah mampu bertepuk tangan saat memasuki usia sembilan sampai dengan duabelas bulan.

Pertumbuhan dan perkembangan anak akan semakin meningkat seiring dengan bertambahnya usia anak. Orangtua perlu memberikan perhatian lebih pada tugas perkembangan anak di usia satu sampai dua tahun. Usia ini adalah usia di mana anak telah memiliki kemampuan berjalan. Memastikan lingkungan main yang aman untuk anak adalah hal yang penting untuk dilakukan mengingat anak akan suka mendorong barang-barang, naik 
turun tangga, melempar barang-barang juga memiliki ketertarikan untuk "menjelajah" tempattempat yang dianggap menarik, misalnya lorong, tangga, ruangan-ruangan kecil dan sebagainya. Orangtua perlu mewaspadai setiap sudut-sudut yang tajam yang ada di setiap ruangan, misal dengan melapisinya dengan kain, spon hati atau menutupnya dengan kain dan sebagainya sebagai antisipasi dari kemampuan eksplorasi anak di saat menghadapi perkembangan motorik kasarnya, berupa kemampuan anak untuk berjalan ke segala penjuru ruangan.

Memasuki usia dua sampai empat tahun anak akan memiliki lebih banyak gerak. Pada usia ini kemampuan motorik kasar anak menjadi lebih berkembang. anak sudah mampu melakukan gerakan-gerakan imitasi, semacam meniru gerakan senam, melakukan gerakan lempar tangkap bola, naik-turun tangga dengan berpegangan dan sebagainya. Biasanya di usia ini anak sudah dapat menerima stimulasi beragam, di usia ini perkembangan anak juga mengalami kepesatan yang luar biasa, karena selain stimulasi yang dilakukan orangtua, kebanyakan anak-anak juga mendapatkan stimulasi-stimulasi dari orang dewasa lainnya, karena biasanya di usia ini anak telah banyak yang tergabung dan menerima layanan pada lembaga-lembaga Pendidikan Anak Usia Dini (PAUD), sehingga aktifitas fisik motorik anak semakin berkembangan dan variatif.

Sampai kepada usia empat hingga enam tahun, anak memiliki kemampuan fisik motorik kasar yang kompleks. Di usia ini stimulasi yang diberikan pendidik maupun orangtua sudah dapat berupa aturan, seperti koordinasi gerakan tangan dan kaki yang lebih kompleks, misal mencuci kaki dan tangan setelah bermain. Menirukan gerakan macam-macam binatang, atau gerakan pohon tertiup angin, atau instruksi-instruksi sederhana yang membutuhkan koordinasi yang lebih kompleks. Stimulasi yang beragam dengan beberapa variasi mampu memberikan sensasi yang berbeda bagi anak-anak, dan tentu saja akan memaksimalkan perkembangan motorik kasar anak itu sendiri.

\section{Pengembangan Motorik Kasar di TK Bina Bhakti Sari}

Lembaga Pendidikan Anak Usia Dini (PAUD) memiliki kesempatan yang lebih luas dalam pengembangan motorik anak. kesadaran orangtua akan pentingnya pendidikan anak sejak dini memberikan kesempatan kepada lembaga PAUD untuk berinovasi dan semakin mengembangkan diri dengan program-program yang mendukung tumbuh kembang anak. guru-guru PAUD dapat berkreasi dengan menyusun kegiatan-kegiatan main yang dapat memaksimalkan perkembangan motorik anak, baik perkembangan motorik halus maupun 
perkembangan motorik kasar anak, dengan berbagai ragam main yang disediakan. Guru dapat mengambil bagian dalam memberikan pengalaman-pengalaman yang merangsang pertumbuhan dan perkembangan semua potensi anak. pengalaman ini digambarkan dan dimasukkan dalam rancangan pembelajaran (Anita, 2015: 21).

Demikian yang dapat dilakukan di TK Bina Bhakti Sari Pati. Pengembangan motorik kasar di TK Bina Bhakti Sari Pati dapat dilakukan dengan berbagai metode. Metode yang Pertama, yaitu creative learning. Creative learning dapat diartikan sebagai pembelajaran yang menonjolkan unsur kreatifitas. Orang-orang kreatif menggunakan skil-skil praktis dalam banyak hal, dan mereka juga terlibat dalam begitu banyak kegiatan mental melalui konseptualisasi, imajinasi, dan ekspresi dari gagasan mereka (Florence, 2013: 42). Dalam kaitannya dengan pengembangan motorik kasar anak, guru dapat menyiapakan kegiatan dengan alat main sekreatif mungkin. Sebagai seorang guru, mengaplikasikan bebagai permainan di dalam kegiatan belajar mengajar merupakan hal yang wajib dilakukan. Suatu kegiatan belajar mengajar akan dapat berjalan efektif apabila ada berbagai strategi yang digunakan, baik berupa metode, model, pendekatan, maupun teknik (Iva Rifa, 2012: 26). Guru dapat mengajak anak-anak untuk merayap di lantai dengan mengandalkan kekuatan tangan mereka, melewati terowongan meja dengan koordinasi yang lebih kompleks karena anak-anak harus menjaga keseimbangan kepala supaya tidak membentur meja, atau sesekali guru dapat bermain peran dengan mengambil cerita "menangkap kupu-kupu". Bermain peran menangkap kupu-kupu misal guru berperan menjadi anak dan anak-anak (murid) berperan menjadi kupu-kupunya, guru berusaha mengejar anak-anak kesana kemari, sedangkan anakanak akan lari berhamburan sambil mengepakkan tangan mereka menyerupai sayap kupukupu yang sedang terbang. Dengan ide-ide kreatif semacam ini, anak-anak akan bergembira karena dapat bermain sesuka hati, dan di sisi lain anak-anak akan semakin terasah kemampuan motorik kasarnya, karena berlari dan menggerakkan tangan-tangan mereka.

Di dalam pembelajaran kreatif, anak-anak melihat pembelajaran sebagai sebuah proses aktif yang melibatkan mereka semua dalam membuat keputusan, mereka memiliki ruang dan waktu untuk mengeksplorasi gagasan dengan caranya sendiri. Belajar dengan cara yang kreatif, dapat meningkatkan seluruh aspek perkembangan, yang dibutuhkan adalah keterlibatan penuh dari anak-anak (Florence, 2013: 51). Dengan contoh kegiatan main peran "menangkap kupu-kupu" di atas, anak-anak terlibat secara aktif dan penuh dalam kegiatan. Dengan kesepakatan-kesepakatan dan aturan main yang dibuat bersama guru, anak-anak dapat 
melakukan kegiatan main dengan sportif, sehingga apabila terjadi insiden misal tersenggol teman, jatuh, atu misal sedikit berbenturan dengan tangan temannya, anak tidak mudah marah atau tidak menangis, karena sudah bersepakat bahwa apa yang dilakukannya adalah sebuah permainan, yang semua anak terlibat langsung di dalamnya.

Kedua, optimalisasi motorik kasar untuk anak-anak di lembaga PAUD, dapat dilakukan dengan cara mendesain pembelajaran berbasis tema. Model pembelajaran berbasis tema atau dapat dikatakan sebagai pembelajaran tematik adalah model pembelajaran yang mengedepankan tema atau topik sebagai penghubung berbagai kegiatan yang dipelajari oleh anak. Sebagaian orang menyebut pembelajaran berbasis tema ini dengan pembelajaran tematik terpadu. Pembelajaran tematik terpadu merupakan suatu penyajian pembelajaran yang menyajikan beberapa mata pelajaran (kegiatan main), dengan tema sebagai pemersatunya (Wachyu, 2014: 168). Guru dapat mengambil suatu tema untuk mengembangkan seluruh aspek perkembangan anak termasuk perkembangan motorik kasar anak, sebagaimana contoh kegiatan main " menangkap kupu-kupu", main peran di atas selain berfokus untuk mengembangkan motorik kasar anak, juga dapat mengembangkan aspek perkembangan anak yang lainnya seperti pengembangan bahasa.

Pengembangan bahasa pada kegaitan main di atas, dapat dilihat dengan adanya penambahan perbendaharaan kata yang dimiliki anak, seperti anak mengetahui banyak kosa kata yang berhubungan dengan kupu-kupu (terbang, bunga, sayap, warna), anak juga dapat terasah kemampuan kognitifnya misal dengan menghitung jumlah sayap yang dimiiki oleh kupu-kupu, jumlah mata kupu-kupu, jumlah bunga yang dihinggapi, dan sebagaianya. Dengan demikian pembelajaran tematik tidak hanya berfokus pada salah satu aspek perkembangan yang dimiliki oleh anak saja, tetapi dapat meliputi seluruh aspek perkembangan yang dimiliki oleh anak, sebagian ahli berpendapat bahwa model pembelajaran tematik inilah yang dianggap paling sesuai dan cocok diterapkan pada jenjang PAUD.

Ketiga, stimulasi yang dapat dilakukan untuk memaksimalkan motorik kasar anak adalah dengan menggunakan media. Media di dalam hubungannya dengan pembelajaran anak usia dini dapat diartikan sebagai alat peraga. Yang dimaksudkan dengan alat peraga adalah media alat bantu pembelajaran, dan segala macam benda yang digunakan untuk memperagakan materi pelajaran (Azhar Arsyad, 2013: 9). Media merupakan bagian penting yang tidak boleh dilalaikan keberadaannya di dalam konteks pembelajaran anak. Media merupakan alat untuk menyederhanakan konsep yang harus dipahami oleh anak. 
Media atau alat peraga memiliki banyak fungsi bagi pembelajaran di PAUD. Salah satu fungsi media adalah fungsi atensi. Fungsi atensi merupakan fungsi menarik perhatian anak, dengan adanya media, maka anak-anak akan lebih tertarik dengan pokok bahasan yang disampaikan oleh guru. Misalnya saat guru memberikan pengetahuan tentang proses terjadinya banjir, anak-anak belum dapat membayangkan atau mengetahui mengapa terjadi banjir. Karena proses yang masih abstrak, maka anak-anak akan sulit memahami apa yang disampaikan oleh guru. Akan tetapi dengan penggunaan media, misal guru membuat peraga banjir, seperti adanya gundukan tanah yang tidak ada pohonnya, adanya saluran-saluran air (yang dapat diibaratkan sebagai sungai) yang tertutup sampah, sehingga ketika mendapat guyuran air dari atas (terjadi hujan), maka air hujan tersebut tidak dapat tertampung ke dalam saluran yang penuh dengan sampah, air juga tidak dapat masuk dan terserap ke dalam tanah, akibat hutan-hutan yang sudah gundul tidak ada pehohonan yang menyimpan air. Menerangkan proses terjadinya banjir dengan penggunaan media, tentu saja lebih mudah dilakukan. Anak-anak juga lebih memungkinkan untuk cepat paham dengan konsep tersebut.

Dampak positif penggunaan media sebagai bagian integral pembelajaran di kelas atau sebagai cara utama pembelajaran langsung, dapat dilihat sebagai berikut (Azhar Arsyad, 2013: 25-26).

a. Penyampaian pelajaran (kegiatan main) menjadi lebih baku. Setiap pelajar yang melihat atau mendengar penyajian melalui media, akan menerima pesan yang sama. Meskipun para guru menafsirkan isi pelajaran dengan cara yang berbeda-beda, dengan penggunaan media, ragam hasil tafsiran itu dapat dikurangi sehingga informasi yang sama dapat disampaikan kepada siswa sebagai landasan untuk pengkajian, latihan, dan aplikasi lebih lanjut.

b. Pembelajaran bisa lebih menarik. Media dapat diasosiasikan sebagai penarik perhatian dan membuat siswa tetap terjaga dan memperhatikan. Kejelasan dan keruntutan pesan, daya tarik image yang berubah-ubah, penggunaan efek khusus yang dapat menimbulkan keingintahuan menyebabkan siswa tertawa dan berpikir, yang kesemuanya menunjukkan bahwa media memiliki aspek motivasi dan meningkatkan minat belajar atau keingintahuan anak.

c. Pembelajaran menjadi lebih interaktif dengan diterapkannya teori belajar dan prinsipprinsip psikologis yang diterima dalam hal partisipasi siswa, umpan balik, dan penguatan. 
d. Lama waktu pembelajaran yang diperlukan dapat dipersingkat karena kebanyakan media hanya memerlukan waktu singkat untuk mengantarkan pesan-pesan dan isi pelajaran dalam jumlah yang cukup banyak dan kemungkinannya dapat diserap oleh siswa.

e. Kualitas hasil belajar dapat ditingkatkan bilamana integrasi kata dan gambar sebagai media pembelajaran dapat mengkomunikasikan elemen-elemen pengetahuan dengan cara yang terorganisasikan dengan baik, spesifik, dan jelas.

f. Pembelajaran dapat diberikan kapan dan di mana saja diinginkan atau diperlukan, terutama jika media pembelajaran dirancang untuk penggunaan secara individu.

g. Sikap positif siswa terhadap apa yang mereka pelajari dan terhadap proses belajar dapat ditingkatkan.

h. Peran guru dapat berubah ke arah yang lebih positif, beban guru untuk penjelasan yang berulang-ulang mengenai isi pelajaran dapat dikurangi bahkan dapat dihilangkan sehingga dapat memusatkan perhatian kepada aspek penting lain dalam proses belajar mengajar, misalnya sebagai konsultan atau penasihat siswa.

\section{SIMPULAN}

Usia dini merupakan usia emas seorang anak. Usia dini sering disebut usia emas (golden ages), karena di usia inilah anak mengalami masa peka. Masa di mana otak anak mudah menyerap segala sesuatu yang diajarkan kepadanya. Pertumbuhan dan perkembangan anak di usia dini ini mengalami perkembangan yang sangat pesat, sehingga stimulasi yang diberikan di masa ini sangat penting, untuk mengoptimalkan pertumbuhan dan perkembangan anak.Aspek perkembangan anak di usia dini sangat beragam antara lain yaitu perkembangan nilai agama moral, sosial emosional kemandirian, fisik motorik, kognitif, berbahasa dan aspek perkembangan seni, di mana seluruh aspek perkembangan anak tersebut perlu mendapatkan stimulasi yang seimbang.

Aspek perkembangan anak yang mudah terlihat karena berhubungan dengan aktifitas fisik adalah aspek perkembangan fisik motorik anak, terutama perkembangan motorik kasar anak. perkembangan motorik kasar anak dapat distimulasi sejak dini dengan memperhatikan tugas perkembangan anak di masing-masing usia. Perkembangan aspek motorik kasar anak di TK Bina Bhakti Sari Pati belum terlaksana secara maksimal. Untuk dapat memaksimalkan perkembangan aspek tersebut, maka dapat dilakukan langkah stimulasi motorik kasar yang tepat. Stimulasi motorik kasar tersebut antara lain dapat dilakukan dengan cara pertama mendesain kegiatan main kreatif (creative learning), mengembangkan kegiatan main berbasis 
tema (tematik), dan memaksimalkan peran media, yaitu menggunakan media sebagai alat bantu untuk memudahkan anak dalam melakukan aktifitas atau kegiatan main yang dapat memaksimalkan perkembangan motorik kasarnya.

\section{DAFTAR PUSTAKA}

Anita Yus, Penilaian Perkembangan Belajar Anak Taman Kanak-kanak, cetakan ke-3, Jakarta:Prenada Media, 2015.

Anggani Sudono, Sumber Belajar dan Alat Permainan Untuk Pendidikan Anak Usia Dini, Jakarta: Grassindo, 2000.

Azhar Arsyad, Media Pembelajaran, Jakarta: RajaGrafindo Persada, 2013.

Bambang Sujiono, dkk, Metode Pengembangan Fisik, Jakarta: Universitas Terbuka, 2014.

Denidya Damayanti, Panduan Islami Perawatan Bayi, Yogyakarta: Pinang Merah Publisher, 2013.

DwiHardiyantidan M. Sukiram, Strategi Pengembangan Moral Anak Usia Dini, (Salatiga: Widyasari Press, 2008).

Elizabeth Hurlock, Metode Perkembangan Anak Jilid, Jakarta: PT.Glora Aksara Pratama : 2005.

Florence Beetlestone, Creative Learning ed. Alih bahasa oleh Narulita Yusron, Bandung: Nusa Media, 2013.

Iva Rifa, Koleksi Games Edukatif di dalam dan luar Sekolah, Yogyakarta: FlashBooks, 2012.

Kirania Larasati, Smart Games for Smart Baby, Yogyakarta: Araska, 2009.

Lampiran 1 Peraturan Menteri Pendidikan dan Kebudayaan Republik Indonesia Nomor 137 tahun 2014, Tentang Standar Nasional Pendidikan Anak Usia Dini.

Maimunah Hasan,, Pendidikan Anak Usia Dini, Yogyakarta: DIVA Press, 2015.

Mursyid, Belajar dan Pembelajaran PAUD, Bandung: PT. Remaja Rosdakarya, 2015.

Novaria A.I \& Triton P.B., Cara Pintar Mendampingi Anak, Yogyakarta: Tugu Publisher, 2008.

Reni Akbar dan Hawadi. Psikologi Perkembangan Anak: Mengenal Sifat, Bakat, dan Kemampuan Anak, Jakarta: Grasindo, 2001.

Siti Aisyah,dkk Perkembangan dan Konsep Dasar Pengembangan Anak Usia Dini, Jakarta: Universitas Terbuka, 2008.

Sri Suciati, bahan ajar pendidikan dan latihan profesi guru, Semarang: PLPG, 2015.

UU Sisdiknas No. 20 Tahun 2003

Wachyu Sundayana, Pembelajaran Berbasis Tema, Jakarta: Penerbit Erlangga, 2014.

Winda Gunarti,dkk, Metode Pengembangan Perilaku dan Kemampuan Dasar Anak Usia Dini, Jakarta: Universitas Terbuka, 2008. 